\title{
Critical Analysis of Multi Sectoral Policies related to Marble Industry in Pakistan
}

\author{
Irfan Ahmed Khan ${ }^{1 a}$, Rashid Rehan ${ }^{1 b}$, Khan Shahzada ${ }^{2}$, Muhammad Imran Ahmad ${ }^{3}$, \\ Attaullah Shah ${ }^{4}$
}

RECEIVED ON 23.09.2019, ACCEPTED ON 05.05.2021

\begin{abstract}
Incentive Based (IB) and Command and Control (CAC) instruments are identified in various legislative Acts and Policy documents based on the criteria of environmental economics. Despite the advantages of IB strategies the world of policy making is somewhat locked into the path of traditional approaches such as CAC and pose inertia to move forward in environmental policy making. An ethical shift is inevitable anywhere where there is a market failure and increased social costs and inefficiencies in government interventions to regulate the market. Regulations are discrete steps to address feedbacks in a complex system. Policy evaluation and testing criteria is used to evaluate and test the policies regulating marble extraction and processing in Pakistan. A set of policy and regulatory instruments are selected to be critiqued. The coexisting policy approaches found in the study shall be tested on system dynamics model for developing insights and long-term implications.
\end{abstract}

Keywords: Environmental Economics, Marble Sector, Policy Evaluation, Policy Testing

\section{INTRODUCTION}

$\mathrm{M}$ arble industry being polluter to water, air and land needs investigation on what regulatory pressures exist at present and what measures are contributing towards mitigating air and water pollution. Dimension Stone sector's stakeholders familiarity with air and water pollution, and existing policies that affect the industry needs to be explored [1]. The critical analysis is intended towards current and proposed actions for mitigating the effects and implications of such actions on marble industry. Pakistan being water scarce country needs to adopt two approaches: adaptation and mitigation in water intensive sectors such as dimensions stone sector which is also indirectly prone to be affected by
Climate change [2]. It is desired to examine some traditional and emerging policy instruments for air and water pollution, direct and indirect costs incurring from the current state of industrial operations (Policy costs) and to analyze merits and drawbacks of the policies using environmental economics tools [3]. The dynamic approaches such as system dynamics offer a promising paradigm to study multi-sectoral policies together to develop the insights into the policies that deals with a complex problem of the society, economy and environment of a region. Separate and discrete, nonintegrated efforts of policy making can undermine the very effectiveness of our Provincial Climate Change Policy and National Water Policy [4]. It is imperative to address policy matters in an integrated fashion for instance taxes on marble wastewater

${ }^{1}$ National Institute of Urban Infrastructure and Planning University of Engineering and Technology, Peshawar, Pakistan. Email: a Irfan.ahmed@uetpeshawar.edu.pk, (Corresponding Author), brashid@uetpeshawar.edu.pk

${ }^{2}$ Department of Civil Engineering University of Engineering and Technology, Peshawar, Pakistan.

Email:khanshahzada@uetpeshawar.edu.pk

${ }^{3}$ Department of Chemical Engineering University of Engineering and Technology, Peshawar.

Email: Imran.ahmad@uetpeshawar.edu.pk

${ }^{4}$ Karakorum International University Gilgit. Email: drshah965@ gmail.com

This is an open access article published by Mehran University of Engineering and Technology, Jamshoro under CC BY 4.0 International License. 
discharges and transportation of raw stone and finished products plus water fee policies that can coexist and thus can present conflicts or synergies that can be only seen through simulation runs on models. Grubb, 2013 as cited by [4] suggests CAC for very cost effective technologies and IB strategies for induced technology transformation goals.

'Specialized means' for exploring and understanding the connections between cause and effect variables responsible for environmental quality issues are inevitable. To do this economist use analytical models. In dealing with complex problems where everything is interconnected and is changing over time, Jay. W. Forrester's system dynamics approach, which combines both principles of economics and engineering to model complex problems is an effective modeling approach. Computer based learning environments where space and time is compressed without any monetary burden was given name as 'micro worlds' by Morecroft [5], considered these micro worlds a playground for policymakers to play with their knowledge of business and social systems and to debate on policy and strategy change.

The subject of our critique is evaluation of policies related to dimension stone sector of Pakistan. Despite the advantages of IB strategies the world of policy making is somewhat locked into the path of traditional approaches such as CAC and pose inertia to move forward in environmental policy making. An ethical shift is inevitable anywhere where there is a market failure and increased social costs and inefficiencies in government interventions to regulate the market [6].

Pakistan being signatory to Multilateral Environmental Agreements (MEAs) specially concerning the "climate change" and being one of the most vulnerable country in the world to climate change has recently made policies on climate change, water, environment and many other sectors including industry. There cannot be a single policy addressing all the issues related to dimension stone sector therefore a set of policies and associated legislative Acts are selected for the critical analysis. The instruments selected for the purpose are presented in Table 1. The major focus of the analysis will be around the policies being formulated by Khyber Pakhtunkhwa
(KP) province of Pakistan under 18th amendment in the constitution of Pakistan and other National policies and instruments which are directly related to them.

For the analysis purpose the most densely populated district Buner in KP with marble factories is selected for the data collection and analysis purposes. Pakistan historically was not water stressed but recently it is becoming a water scarce country to the extent that it is feared that by 2025 the country will run out of water as it happened in Cape town South Africa [7].

\begin{tabular}{|c|c|c|}
\hline S/No. & Policies & Acts \\
\hline 1. & $\begin{array}{l}\text { Khyber } \\
\text { Pakhtunkhwa } \\
\text { Climate Change } \\
\text { Policy, 2016 [2]. }\end{array}$ & $\begin{array}{lr}\text { The Khyber } \\
\text { Pakhtunkhwa } \\
\text { Minerals Sector } \\
\text { Governance } \\
2017 \text { [8]. }\end{array}$ \\
\hline 2. & $\begin{array}{l}\text { Khyber } \\
\text { Pakhtunkhwa } \\
\text { Minerals Policy, } \\
2014 \text { [9]. }\end{array}$ & $\begin{array}{l}\text { The Khyber } \\
\text { Pakhtunkhwa } \\
\text { Environmental } \\
\text { Protection Act, } 2014 \\
\text { [10]. }\end{array}$ \\
\hline 3. & $\begin{array}{l}\text { Khyber } \\
\text { Pakhtunkhwa } \\
\text { Industrial Policy, } \\
2016 \text { [11]. }\end{array}$ & $\begin{array}{l}\text { The Khyber } \\
\text { Pakhtunkhwa } \\
\text { Local Government } \\
\text { Act, 2013 [12]. }\end{array}$ \\
\hline 4. & $\begin{array}{l}\text { Khyber } \\
\text { Pakhtunkhwa } \\
\text { Agricultural } \\
\text { Policy, 2014 [13]. }\end{array}$ & $\begin{array}{l}\text { Pakistan } \\
\text { Environmental } \\
\text { Protection Act, } 1997 \\
\text { [14]. }\end{array}$ \\
\hline 5. & $\begin{array}{l}\text { National Water } \\
\text { Policy of Pakistan } \\
2018 \text { [7]. }\end{array}$ & $\begin{array}{l}\text { The Khyber } \\
\text { Pakhtunkhwa } \\
\text { Factories Act, } 2013 \text {, } \\
\text { [15]. }\end{array}$ \\
\hline 6. & & $\begin{array}{l}\text { The Khyber } \\
\text { Pakhtunkhwa } \\
\text { Industrial Relations } \\
\text { Act, 2010 [16]. }\end{array}$ \\
\hline
\end{tabular}

In such circumstances where changing climate is one of the major factor along with the current nonsustainable practices of the industries and people, there is a dire need to work in less water-intensive ways [17]. Water is a limiting factor in our development and at the same time 'climate compatibility development' approach is mandatory for developing mitigation and adaptations strategies in every sector of the country due to international 
obligations on the country being signatory to certain agreements [18].

The outcome of this effort is a set of policies and regulations that are directly or indirectly related to the dimensions stone sector but spread across different sectors of development and regulation. The set of the instruments, policies and regulations will be evaluated on efficiency, cost effectiveness, enforceability, fairness, flexibility, technologically adaptive and morally considerate yet not conflicting or overlapping [3]. The resulting policies scenarios will be tested later on a model developed on a system dynamics software.

\section{BACKGROUND}

Dimension stone sector is water intensive in its processing operations [19]. 9.6 million liters of ground water is being extracted on daily basis in Buner $\mathrm{KP}$, which is quite comparable with the European stone blocks extraction that corresponds to the loss of about 1.98 billion liters of water per year [20]. Being water scarce country at one end and threatening the ground water on the other while being vulnerable to climate change, immediately demands mitigation and adaptive measures at all levels [18]. The Climate change policy mandates all other policies to be in line with it following 'climate compatible development' framework to mitigate and adapt for the climate change effects. Translating the various guidelines into actions through regulations on dimension stone sector in Pakistan will greatly affect marble industry. In current state of affairs, it might cease to operate further, which will affect the livelihood of a large proportion of population of the area, Leaving it as it is may not be an option anymore for current environmental conditions of the district. Pakistan Stone Development Company (PASDEC) is also facing 'perverse incentives' of their policies. The major stakeholders of the system under consideration are Association of Owners of Marble factories/Industry, Environmental Protection Agency (EPA), district administration, judiciary and society at large in the district.

There are concerns about differing protection regimes in different provinces [21]. A consequence of the Eighteenth Amendment in the constitution of Pakistan and its effects on Pakistan Environmental Protection Acts is that Procedural difficulties and inter-provincial conflict can result. Also, since Multilateral Environmental Agreements (MEAs) are Pakistan's international obligation and come under federal jurisdiction. Provincial EPAs not being delegated the powers on matters on Federal list. New instruments are needed to cover matters, which are not yet properly been addressed in the environmental laws [21]. In the last five years of government in KP a lot has been done in policy making, few of the efforts are given in Table 1.

\subsection{ASSUMPTIONS}

Before taking a position on the critical analysis the assumptions made are as follows:

1. The use of water is a limiting factor in the growth of dimension stone sector in Pakistan. Since regions in the country are becoming water scarce due to climate change to which the country is one of the most vulnerable in the world [18], any regulation regarding water resource consumption and management will directly affect the growth of dimension stone sector.

2. It is assumed that in spite of provincial EPAs being established in the country the agencies and line departments are unable to address the issue of environment on its merits. A case of policy failure, in other words government failure.

3. Thirdly there are presumably some perverse incentives somewhere in the mining and mineral policy/Act and industrial policy which is rendering environmental policies ineffective and inefficient.

4. The fourth assumption is that regulators and law makers are sticking to the strict CAC policies, which apparently seem very pertinent but actually not serving the intended purpose.

"Any system will produce destructive environmental impacts if the incentives within the system are not structured to avoid them" [3].

Dimension stone sector needs to be investigated for IB strategies for a reasonable progressive economic growth without adverse environmental effects [3]. 
One of the research questions addressed in this paper as highlighted by the Organization for Economic Cooperation and Development (OECD) (1997) is to find the intersectoral concerns related to environment being neglected in environmental Act 1997, which is said to be focused mostly on National Environmental Quality Standards (NEQs). Briefly the climate change policy, national water policy, industrial policy, and major legislations and instruments of KP Province after the eighteenth amendment are being evaluated on the basis of efficiency, cost effectiveness, equity, enforceability flexibility, room for technological innovation and moral nuance keeping strictly the economic principles governing the growth of dimension stone sector in general restricted to the industry in Buner district of KP Pakistan. An Overview of the policies to be critiqued is as follows.

\subsection{Overview of Policies and Acts}

A summary of policies and acts is presented in Table 2.

\begin{tabular}{|c|c|c|}
\hline S/No. & Policies & Overview \\
\hline 1. & $\begin{array}{lr}\text { Khyber } & \text { Pakhtunkhwa } \\
\text { Climate } & \text { Change } \\
\text { Policy, } 2016 \text { [18]. }\end{array}$ & $\begin{array}{l}\text { Goal is to steer KP towards 'green growth' and 'climate compatible } \\
\text { development'. } \\
\text { Encourage water conservation by sustainable ground water } \\
\text { exploitation, recycling of wastewater through proper treatment and } \\
\text { its reuse (H). } \\
\text { - Develop contingency plans for short term measures to adapt to water } \\
\text { shortages that could help to mitigate droughts and floods (H). } \\
\text { Protect groundwater through management and technical measures } \\
\text { like regulatory frameworks, water licensing, artificial recharge } \\
\text { especially for threatened aquifers, and adopt integrated water } \\
\text { resources management concepts and practices (H). } \\
\text { Legislate and enforce industrial and domestic waste management } \\
\text { practices to protect water resources from further degradation (M). } \\
\text { Enact and enforce laws and regulations required for efficient water } \\
\text { resource management (H). } \\
\text { Encourage cleaner production and propagate 'circular economy' } \\
\text { concept for efficient use of resources based on UNEP's Sustainable } \\
\text { consumption and production guidelines (M). } \\
\text { Determine technological needs in the province for climate mitigation } \\
\text { and adaptation by conducting technology needs assessment (H). } \\
\text { H: high; M: medium and L: low priorities. }\end{array}$ \\
\hline 2. & $\begin{array}{l}\text { Khyber Pakhtunkhwa } \\
\text { Minerals Policy, } 2014 . \\
\text { [22] }\end{array}$ & $\begin{array}{l}\text { The core policy principles related to our study area are; } \\
\text { - Preference to be given to integrated mining operations with linkages } \\
\text { to upstream (pre-production, production and transportation and } \\
\text { downstream (processing) and other mining related activities; } \\
\text { - Formulation of a fiscal and regulatory regime ensuring fair value for } \\
\text { KP while offering equitable rewards to private investors; } \\
\text { Ensuring predictable mechanisms for the evaluation of competing } \\
\text { land, water and other resource-use options; } \\
\text { - Eliminating and mitigating adverse social conditions and } \\
\text { environmental degradation attributed to mining related activities; } \\
\text { - Ensuring fair distribution of benefits from mining and related } \\
\text { activities to meet current and future public needs; } \\
\text { Establishment of an effective and transparent administration and } \\
\text { management of the mineral sector; } \\
\text { Giving preference to local value addition and processing of } \\
\text { indigenous minerals. }\end{array}$ \\
\hline
\end{tabular}

Mehran University Research Journal of Engineering and Technology, Vol. 41, No. 1, January 2022 [p-ISSN: 0254-7821, e-ISSN: 2413-7219] 


\begin{tabular}{|c|c|c|}
\hline & & $\begin{array}{l}\text { Main aims of the regulatory framework revolve around ease of business and } \\
\text { economic growth encompassing leases, operations and performance } \\
\text { altogether. Defining the transition from exploration to mining rights and the } \\
\text { transfer of these rights; Regulating the conduct of mining and labour welfare, } \\
\text { including mine closure plan; Guarantee security of tenure and the orderly, } \\
\text { uninterrupted carrying out of business. Specifying penalties for violations of } \\
\text { law, license requirements, rules and regulations; Ensuring exclusivity of } \\
\text { specified mineral rights over licensed areas. }\end{array}$ \\
\hline 3. & $\begin{array}{l}\text { Khyber Pakhtunkhwa } \\
\text { Industrial Policy, 2016, } \\
\text { [11]. }\end{array}$ & 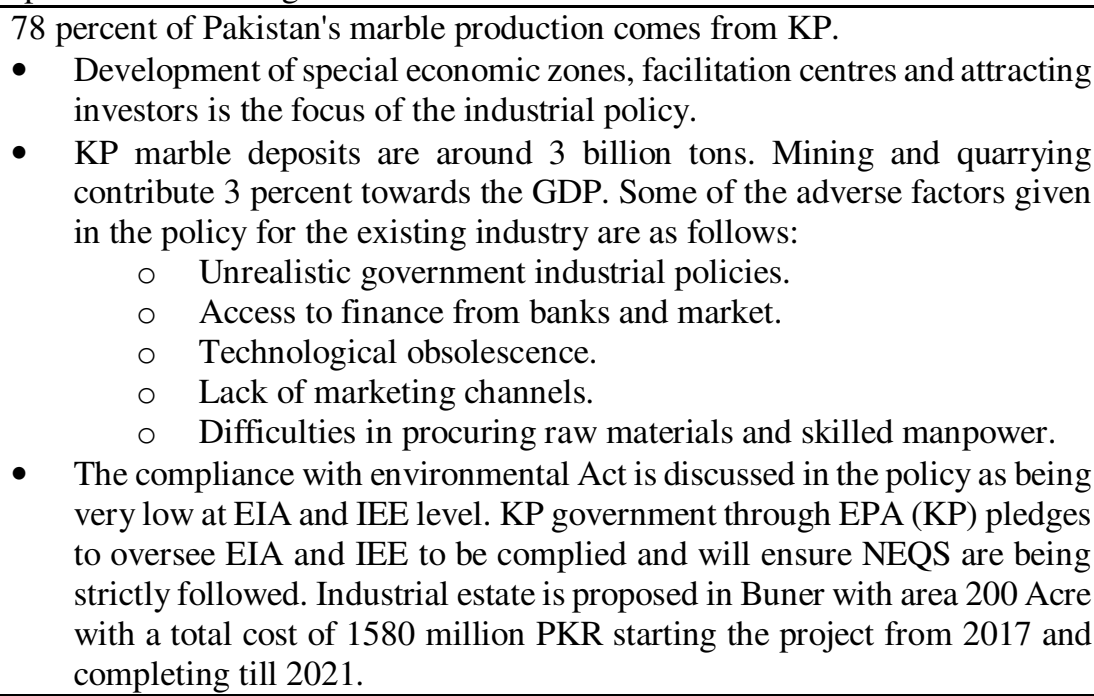 \\
\hline 4. & $\begin{array}{l}\text { Khyber Pakhtunkhwa } \\
\text { Agricultural Policy, } \\
2014[13] .\end{array}$ & $\begin{array}{l}\text { The economy of KP is said to be agrarian because of its } 80 \text { percent population } \\
\text { being rural, with agriculture as major livelihood source. Agriculture sector } \\
\text { being contributor of } 22 \text { percent to provincial GDP is facing challenges due to } \\
\text { climate change and water scarcity. }\end{array}$ \\
\hline 5. & $\begin{array}{l}\text { National Water Policy } \\
\text { of Pakistan } 2018 \text { [7]. }\end{array}$ & $\begin{array}{l}\text { - Pakistan's per capita surface water availability has declined from } 5,260 \\
\text { cubic meters per year in } 1951 \text { to around } 1,000 \text { cubic meters in } 2016 \text { and } \\
\text { is likely to further drop to about } 860 \text { cubic meters by } 2025 \text { trending to } \\
\text { become water scarce country. } \\
\text { Fresh water becoming scarcer, country in heat surplus zone, increased } \\
\text { stress on water resources sharing, bulk of water requirement met by } \\
\text { groundwater, which is depleting, mandates of provincial and federal } \\
\text { governments need clarity, water recycling and wastewater reuse are the } \\
\text { major issues highlighted in the policy document. } \\
\text { The Policy is aimed at following: promotion of sustainable consumption, } \\
\text { reliability and quality of fresh water for various uses, reducing non- } \\
\text { revenue water and handling industrial effluents, helping adapting to } \\
\text { climate change, reuse of water, restoration and maintenance of } \\
\text { ecosystems, safety and security of water streams, rain water harvesting in } \\
\text { rural and urban areas, aquifer recharge promotion and regulating } \\
\text { groundwater abstraction. } \\
\text { Conservation and efficiency, storage, technology adoption, protection of } \\
\text { water shed and catchment areas under IWRM, comprehensive regulation } \\
\text { for ground water utilization and other uses, with planning principles } \\
\text { focusing on fairness, enforceability and flexibility and maximum } \\
\text { outreach. } \\
\text { The water uses are prioritized as follows: } 1 \text {. Drinking and Sanitation } \\
\text { (WASH). 2. Irrigation including land reclamation. } 3 \text {. Livestock, fisheries } \\
\text { and wildlife. } 4 \text {. Hydropower. 5. Industry and mining. 6. Environment, }\end{array}$ \\
\hline
\end{tabular}

Mehran University Research Journal of Engineering and Technology, Vol. 41, No. 1, January 2022 [p-ISSN: 0254-7821, e-ISSN: 2413-7219] 


\begin{tabular}{|c|c|c|}
\hline & & $\begin{array}{l}\text { river system, wetlands, aquatic life. } 7 \text {. Forestry including social forestry. } \\
8 \text {. Recreation and sports. } 9 \text {. Navigation. }\end{array}$ \\
\hline & ACTS & Overview \\
\hline 1. & $\begin{array}{l}\text { The Khyber } \\
\text { Pakhtunkhwa Minerals } \\
\text { Sector Governance } \\
\text { Act, 2017, [8]. }\end{array}$ & 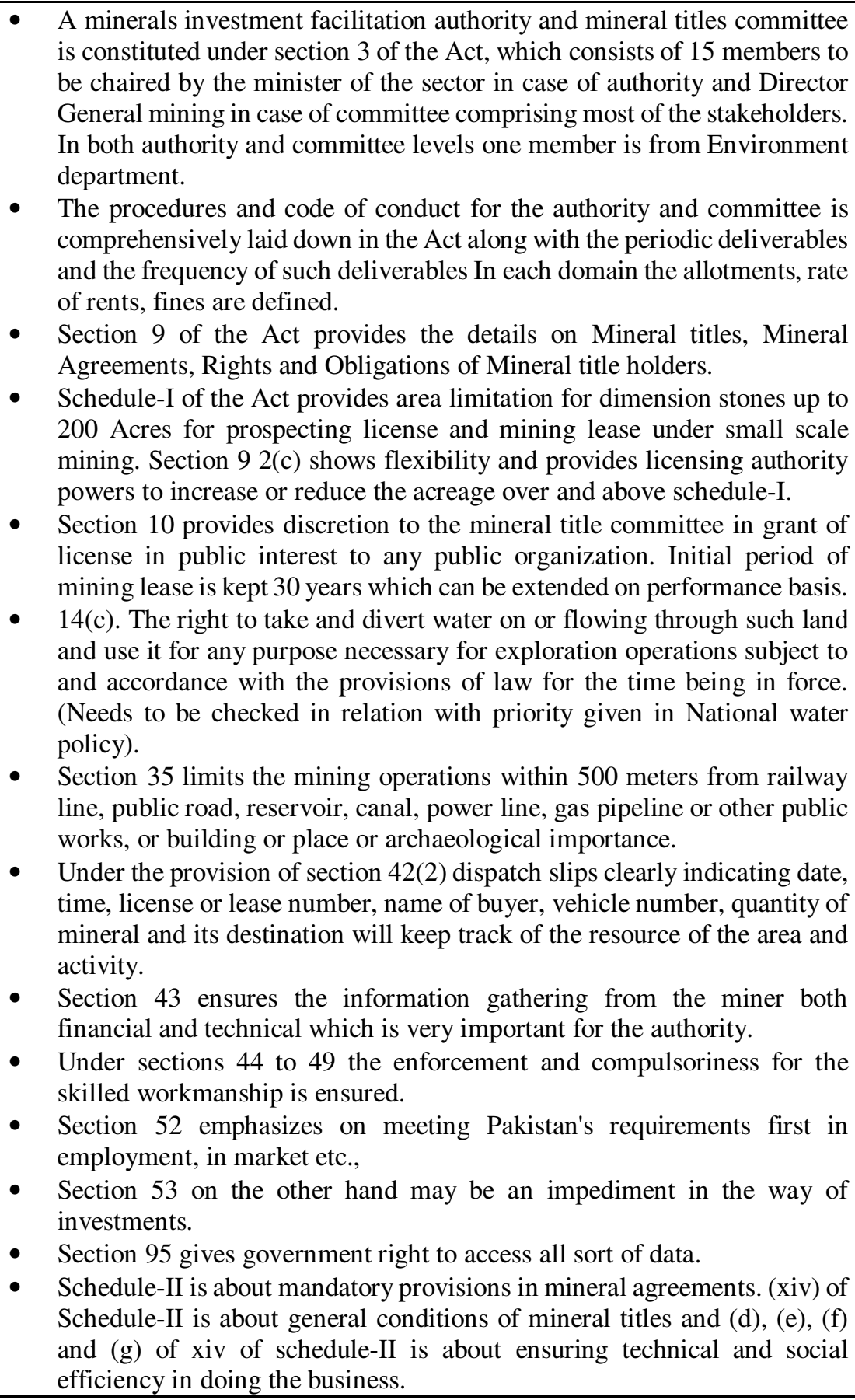 \\
\hline 2. & $\begin{array}{l}\text { The Khyber } \\
\text { Pakhtunkhwa } \\
\text { Environmental } \\
\text { Protection Act, 2014, } \\
\text { [10]. }\end{array}$ & $\begin{array}{l}\text { - The environmental protection agency EPA was established under Pakistan } \\
\text { Environmental Protection Act, } 1997 \text { is working now under this Act, } 2014 \text {. } \\
\text { Implementation of the environmental policies is mandate of EPA and } \\
\text { policy formulation is mandate of Environmental Protection Council. } \\
\text { There are } 41 \text { sections in all } 1 \text { to } 40 \text { and } 41 \text { st being the 7A. It is envisioned } \\
\text { "to provide for the protection, conservation, rehabilitation and } \\
\text { improvement of the environment, for the prevention and control of }\end{array}$ \\
\hline
\end{tabular}




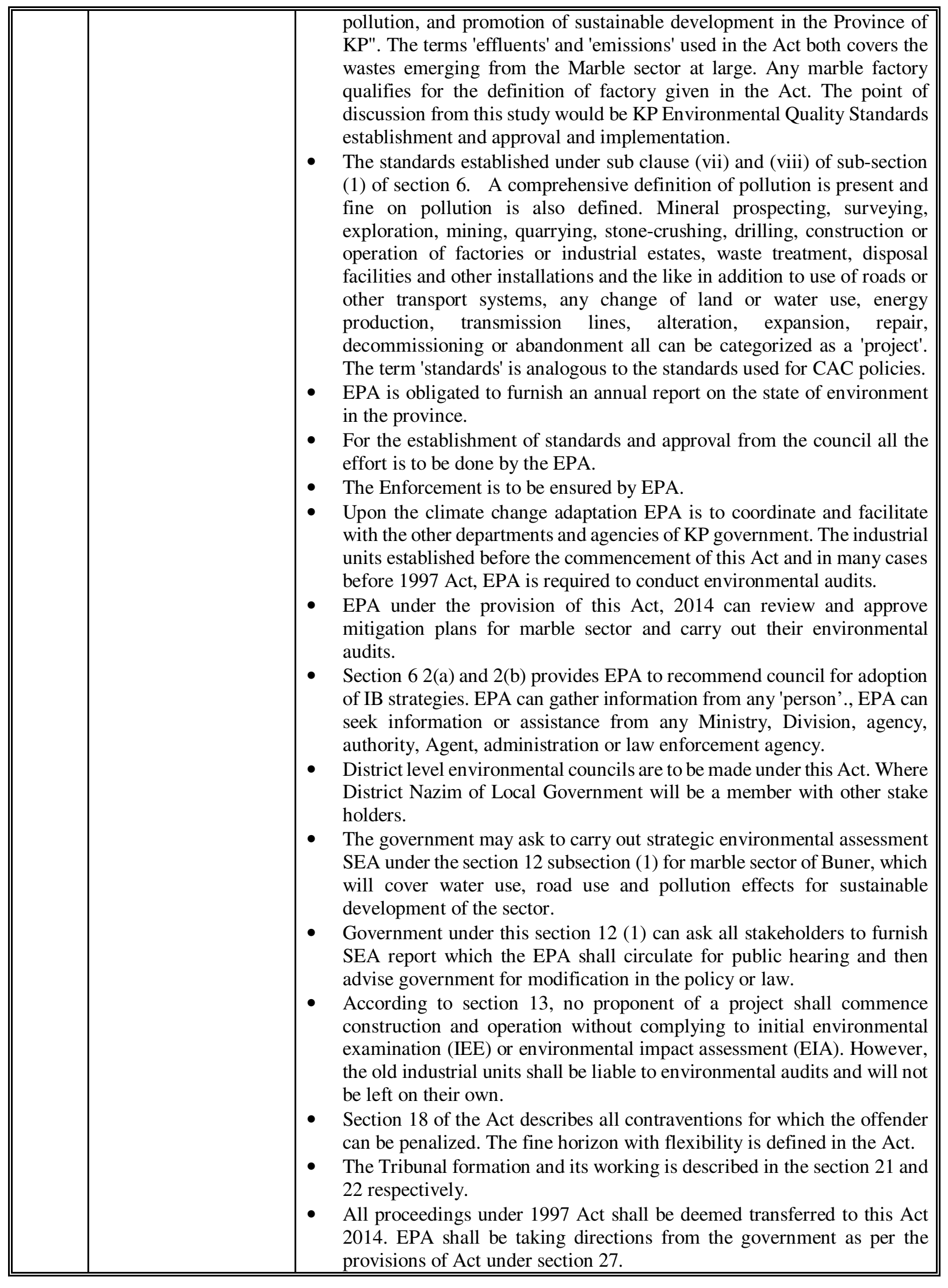

Mehran University Research Journal of Engineering and Technology, Vol. 41, No. 1, January 2022 [p-ISSN: 0254-7821, e-ISSN: 2413-7219] 


\begin{tabular}{|c|c|c|}
\hline & & $\begin{array}{l}\text { - Section } 30 \text { gives overriding effect to the Act where any inconsistency in } \\
\text { other laws are found. } \\
\text { - Section } 32 \text { gives the power to the Government to amend laws and rules to } \\
\text { comply with the MEAs which are specified separately as a SCHEDULE } \\
\text { at the end of this document. }\end{array}$ \\
\hline 3. & $\begin{array}{lr}\text { The } & \text { Khyber } \\
\text { Pakhtunkhwa } & \text { Local } \\
\text { Government } & \text { Act, } \\
2013,[12] . & \end{array}$ & $\begin{array}{l}\text { - The Article } 37 \text { of the constitution of Pakistan requires decentralization of } \\
\text { government. } \\
\text { Article 140-A of the constitution provides for establishment of local } \\
\text { government system for devolution of political, administrative and } \\
\text { financial responsibility and authority to elected representatives. } \\
\text { Even at the village level the local government is to bear the responsibility } \\
\text { for improved water supply sources, maintenance of water supply } \\
\text { distribution and to take measures to prevent contamination of water. } \\
\text { The local government has the right to tax and manage the affairs at their } \\
\text { unit level. } \\
\text { - Section } 42 \text { of the Act provides for the taxation rules. } \\
\text { Section } 71 \text { (a, b, c, d and e) provides for general powers of enforcement } \\
\text { officers i.e., in case of any serious threat to public health, safety or welfare } \\
\text { or danger to life or property the officer may suspend any work, seize the } \\
\text { goods, seal the premises; demolish or remove work; or issue directions for } \\
\text { taking corrective measures within a specified time. } \\
\text { Section } 72 \text { limits the officer to first attain a search warrant, which means } \\
\text { for environmental concerns direct clauses from Environmental Acts will } \\
\text { be needed to get such warrants. } \\
\text { Schedule-VII part } 2 \text { recommends on points } 23 \text { and } 38 \text { to provide bye laws } \\
\text { which are related to the prevention of air, water and soil and to the } \\
\text { pollution of air, water or soil. Under the same schedule the point number } \\
15 \text { refers to an annexure which is named 'dangerous and offensive articles } \\
\text { and trades', among many other things point } 22 \text { refers to marble cutting and } \\
\text { polishing which asks for bye laws in the Act. }\end{array}$ \\
\hline 4. & $\begin{array}{l}\text { Pakistan } \\
\text { Environmental } \\
\text { Protection Act, 1997, } \\
{[14] .}\end{array}$ & $\begin{array}{l}\text { After the adoption of KPEPA, } 2014 \text { ACT, the } 1997 \text { ACT document is used for } \\
\text { reference only. }\end{array}$ \\
\hline 5. & $\begin{array}{l}\text { The Khyber } \\
\text { Pakhtunkhwa Factories } \\
\text { Act, 2013, [15]. }\end{array}$ & $\begin{array}{l}\text { - The term factory do include a marble factory in its definition however a } \\
\text { mine is not included. } \\
\text { - Section } 7 \text { gives power to the government to exempt a factory from the Act } \\
\text { in case the number of employs is less than } 10 \text { for last } 12 \text { months period } \\
\text { and at the same time if the workers are more than ten the exemption will } \\
\text { be ceased. } \\
\text { - Under section } 15 \text { proper disposal of wastes and effluents is mandatory on } \\
\text { factory manager or owner. The rules are not explicit and regulation is yet } \\
\text { to be done on this section. } \\
\text { - Section } 17 \text { is on the dust and fume and its enforcement in Marble sector } \\
\text { is must for the safety of workers. } \\
\text { The Act in general provides for the worker safety, maintainability of the } \\
\text { factory and livelihood of associated with workers and at the same time for } \\
\text { the environmental protection. }\end{array}$ \\
\hline 6. & $\begin{array}{l}\text { The Khyber } \\
\text { Pakhtunkhwa } \\
\text { Industrial Relations } \\
\text { ACT, 2010, [16]. }\end{array}$ & $\begin{array}{l}\text { "To formulate the law relating to formation of trade unions, regulation and } \\
\text { improvement of relations between employers and workmen". Not discussed in } \\
\text { this article. }\end{array}$ \\
\hline
\end{tabular}




\subsection{HIGHLIGHTS FROM OTHER STUDIES ON MARBLE SECTOR AND ASSOCIATED POLICIES}

85 percent wastage at quarrying is attributed towards leasing irregularities that are leading to uncontrolled illegal blasting and resistance to adopt modern extraction techniques. Taxation and duties structure are also reportedly offering disincentive instead of incentivizing the value addition. It is highly emphasized to resolve regulatory and duty regimes to harvest any sort of impact through interventions such as made by PASDEC. Standardization of dimension stone's quality and its infrastructure requirement needs to be assessed and immediately adopted to cope with International market. The lack of standards is also attributed to 'lack of a cohesive organizational framework'. The waste of the dimension stone sector from the factories is a nuisance but very rightly reported that " it adds to the cost of the final product " plus a " missed opportunity to take advantage of secondary uses for the waste" [23]. A number of symbiotic relationships can be developed between marble sector and other industries especially when industrial symbiosis is seen in the context of availability of raw materials (waste of one industry) to other industry within certain proximity [24]. There are some proposed interventions related to our critical literature analysis in Table 3.

Mineral sector is operating under highly unregulated markets and also under incomplete framework [25]. In 2013 it was proposed to develop model quarry in Buner district. Table 4 highlights challenges faced by KP Mineral Development.

Pakistan Environmental Protection Act (PEPA) 1997 had overriding effect on all other laws of Pakistan, however after 2010 that is not the case anymore [21]. A few issues are raised regarding "international treaties, conventions and agreements related to the environment (implementation of treaties, reporting)". Similarly regarding "Inter-provincial coordination in environmental matters (uniformity in emission standards, EIA procedures and requirements, penalties); the extent of influence that provincial governments will have in the decisions of the council of common interests". Other issues such as climate change, sustainable development, foreign loans and aid, taxation (green taxes) etc. are the issues of concern to be addressed at policy levels. The issues of overlap and duplication such as in local government laws, development authority laws and laws governing industry and processes pose a challenge and an opportunity to develop a proper hierarchy for the environment protection [21]. Strategic Environmental Assessment (SEA) is suggested to be included in country's laws. "Environmental audits covering all types of industrial and commercial operations", integration of "polluter pays" principle, cross boundary pollution issues between the provinces [21].

Under a Technology development fund TDF project named "Envisioning zero waste in Marble sector of Pakistan; A dynamic approach" funded by Higher Education Pakistan HEC, research is undertaken where it is hypothesized that solutions of complex problems such as marble sector being user of water, power and road infrastructure and at the same time not growing well economically yet deteriorating the environment at high rates are not simple. Also, PASDEC failing to achieve growth in sector and obvious environmental problems call for finding the leverage points in the system to address this dilemma for which this critical analysis is carried out.

\section{CRITIQUE}

The consequences, water quality deterioration, recharge problems, loss of biodiversity, health issues, loss of recreational locations near water bodies, at quarry site, deterioration of roads frequently due to overloading or uncontrolled loading, old technology, uncontrolled blasting and lack of skills are problems that invoke regulation [27]. Socially efficient level of effluent discharge is that level at which 'marginal abatement costs' equal 'marginal damage costs'. To maintain such levels of effluents from dimension stone sector 'enforcement costs' must also be known, which arise due to regulations and their enforcements [28]. The available public policy approaches pertinent to this study are as follows:

Command-and-control policies

Standards 
Incentive-based policies

Taxes and subsidies

Transferable discharge permits

The criteria for evaluating policies related to dimension stone sector is taken from [3]. The criteria to be used is as follows

- Efficiency.

- Cost-effectiveness.

- Fairness.
- Incentive for technological innovations

- Enforceability.

- Agreement with moral percepts.

Among the public policy approaches only CAC policies and presence or absence of IB policies are identified in the selected policy instruments in this study and the same are being evaluated on the criteria mentioned above.

\begin{tabular}{|c|c|c|c|c|}
\hline \multicolumn{5}{|c|}{ Table 3. Proposed interventions for Marble Value Chain in Pakistan [23] } \\
\hline Proposed intervention & $\begin{array}{l}\text { Expected } \\
\text { Impact }\end{array}$ & $\begin{array}{l}\text { Time Frame } \\
\text { to Realize } \\
\text { Impact }\end{array}$ & $\begin{array}{l}\text { Key issues to } \\
\text { Implementation }\end{array}$ & $\begin{array}{c}\text { Sector } \\
\text { Champion }\end{array}$ \\
\hline \multicolumn{5}{|c|}{ Policy Issues } \\
\hline $\begin{array}{l}\text { Introduce a regulatory framework on } \\
\text { mining techniques (ban explosives) }\end{array}$ & $\begin{array}{l}\text { Reduce } \\
\text { wastage by } 30 \\
\text { to } 40 \%\end{array}$ & Immediate & $\begin{array}{l}\text { Promote } \\
\text { advocacy and } \\
\text { cost-benefit } \\
\text { analysis }\end{array}$ & $\begin{array}{l}\text { PASDEC and } \\
\text { key firms with } \\
\text { integrated } \\
\text { value chain }\end{array}$ \\
\hline $\begin{array}{l}\text { Strengthen contract frameworks through } \\
\text { assistance to PASDEC }\end{array}$ & $\begin{array}{l}\text { Improve } \\
\text { property rights } \\
\text { in sector }\end{array}$ & Short-term & $\begin{array}{l}\text { Promote } \\
\text { advocacy efforts }\end{array}$ & PASDEC \\
\hline $\begin{array}{l}\text { Promote reduction in tariff duties for } \\
\text { equipment and materials }\end{array}$ & $\begin{array}{l}\text { Increase value- } \\
\text { added } \\
\text { production }\end{array}$ & Short-term & $\begin{array}{l}\text { Promote } \\
\text { advocacy efforts }\end{array}$ & PASDEC \\
\hline \multicolumn{5}{|c|}{ Standards and Technology } \\
\hline $\begin{array}{l}\text { Provide funding to Dimension Stone } \\
\text { Evaluation Center (DSEC) to conduct } \\
\text { R\&D for alternatives to blasting and } \\
\text { efficient use of marble waste }\end{array}$ & $\begin{array}{l}\text { Enhance value } \\
\text { added in } \\
\text { sector, reduce } \\
\text { costs }\end{array}$ & $\begin{array}{l}\text { Medium } \\
\text { term }\end{array}$ & & DSEC \\
\hline $\begin{array}{l}\text { Provide firm level technical assistance to } \\
\text { factory owners to adopt new technologies }\end{array}$ & $\begin{array}{l}\text { Improved } \\
\text { productivity }\end{array}$ & Short term & $\begin{array}{l}\text { Identifying lead } \\
\text { firms }\end{array}$ & $\begin{array}{l}\text { PASDEC, } \\
\text { APMIA }\end{array}$ \\
\hline Strengthen standards framework & $\begin{array}{l}\text { Increased } \\
\text { adoption of } \\
\text { standards }\end{array}$ & $\begin{array}{l}\text { Medium- } \\
\text { term }\end{array}$ & $\begin{array}{l}\text { Upgrade } \\
\text { management } \\
\text { technical capacity } \\
\text { at PCSIR and } \\
\text { likes }\end{array}$ & $\begin{array}{l}\text { PCSIR/ } \\
\text { Private labs }\end{array}$ \\
\hline $\begin{array}{l}\text { Funding to geological institutes to } \\
\text { conduct testing on stone specifications } \\
\text { and develop database }\end{array}$ & $\begin{array}{l}\text { Enhance } \\
\text { market } \\
\text { information } \\
\text { for buyers }\end{array}$ & Short term & & $\begin{array}{l}\text { Geological } \\
\text { Institutes }\end{array}$ \\
\hline \multicolumn{5}{|c|}{ Workforce Development } \\
\hline $\begin{array}{l}\text { Enhance the process of establishing } \\
\text { model mine facilities }\end{array}$ & $\begin{array}{l}\text { Increase value } \\
\text { added } \\
\text { production }\end{array}$ & $\begin{array}{l}\text { Medium } \\
\text { term }\end{array}$ & $\begin{array}{l}\text { Collaboration } \\
\text { between mine } \\
\text { owners and local } \\
\text { administration } \\
\end{array}$ & PASDEC \\
\hline $\begin{array}{l}\text { Support PASDEC efforts to train } \\
\text { operators and maintenance personal in } \\
\text { connection to development of machinery } \\
\text { pools for the mining sub segment }\end{array}$ & $\begin{array}{l}\text { Strengthen } \\
\text { workforce } \\
\text { skills }\end{array}$ & Short term & Financing & PASDEC \\
\hline $\begin{array}{l}\text { Develop skills for marble mosaic } \\
\text { including those needed for marketing } \\
\text { products }\end{array}$ & $\begin{array}{l}\text { Strengthen } \\
\text { workforce }\end{array}$ & $\begin{array}{l}\text { Medium } \\
\text { term }\end{array}$ & $\begin{array}{l}\text { Identification of } \\
\text { target women's } \\
\text { organizations }\end{array}$ & PASDEC \\
\hline
\end{tabular}

Mehran University Research Journal of Engineering and Technology, Vol. 41, No. 1, January 2022 [p-ISSN: 0254-7821, e-ISSN: 2413-7219] 


\begin{tabular}{|c|c|c|}
\hline \multicolumn{3}{|c|}{ Table 4: Institutional gaps in KP Mineral Development Department [26] } \\
\hline Issue & Institutional Gaps & Need for Strengthening \\
\hline Inspection of Mines & $\begin{array}{l}\text { Investor, Government and public understanding } \\
\text { of inspectorate may be improved }\end{array}$ & $\begin{array}{l}\text { Inspectorate at MDD, } \\
\text { regularization of inspections, } \\
\text { strengthened enforcement power }\end{array}$ \\
\hline Land rights & $\begin{array}{l}\text { Clear policies on land use and land access for } \\
\text { mining may be developed }\end{array}$ & $\begin{array}{l}\text { Forestry Department, Land } \\
\text { department, Environmental } \\
\text { protection department }\end{array}$ \\
\hline $\begin{array}{l}\text { Resettlement/ } \\
\text { Compensation }\end{array}$ & $\begin{array}{l}\text { Existing law and institutions may not be } \\
\text { sufficient to address modern mining needs }\end{array}$ & Land Department \\
\hline Environment & Virtually not addressed; Urgent Issue! & $\begin{array}{l}\text { Environmental Protection } \\
\text { Department }\end{array}$ \\
\hline $\begin{array}{l}\text { Dispute/Conflict } \\
\text { Resolution }\end{array}$ & $\begin{array}{l}\text { Formal guidelines, institutions for various } \\
\text { disputes not clear }\end{array}$ & $\begin{array}{l}\text { MDD can play role District } \\
\text { governments role here }\end{array}$ \\
\hline Foreign Investment & $\begin{array}{l}\text { How federal provincial agencies are to interact } \\
\text { with investor }\end{array}$ & $\begin{array}{l}\text { Financial and foreign investment } \\
\text { institutions must develop clear } \\
\text { policies and protocols }\end{array}$ \\
\hline Public Information & $\begin{array}{l}\text { Formal, regularized communication program } \\
\text { not in place; media training on mining will be } \\
\text { useful }\end{array}$ & MDD can play its role \\
\hline $\begin{array}{l}\text { Stakeholder } \\
\text { participation }\end{array}$ & $\begin{array}{l}\text { Nascent civil society must be supported to build } \\
\text { citizen participation }\end{array}$ & $\begin{array}{l}\text { Provincial government approaches } \\
\text { to more actively include citizens in } \\
\text { mining }\end{array}$ \\
\hline Worker protection & Inactive union/worker associations & $\begin{array}{l}\text { MDD and Labor Department can } \\
\text { focus more attention here }\end{array}$ \\
\hline $\begin{array}{l}\text { Skills training, } \\
\text { education }\end{array}$ & $\begin{array}{l}\text { No structured or strategic training in place for } \\
\text { provincial residents- institutes, schools, } \\
\text { university curriculum needed }\end{array}$ & \\
\hline $\begin{array}{l}\text { Financing sector } \\
\text { reform }\end{array}$ & $\begin{array}{l}\text { Provincial "Mineral Sector Reform" initiative } \\
\text { may be supported to bring together key } \\
\text { stakeholders }\end{array}$ & $\begin{array}{l}\text { MDD can work with provincial } \\
\text { government, donors }\end{array}$ \\
\hline
\end{tabular}

\subsection{Efficiency}

"An efficient policy is one that moves us to, or near, the point (either of emissions or of ambient quality) where 'marginal abatement costs' and 'marginal damages' are equal." The point of emissions or ambient quality gives the conceptuality of the policy or instrument. The point of focus is equal 'abatement costs' and 'marginal damages' and for that point centralized policies such as CAC rely on regulatory agency for which the agency needs appropriate knowledge of the abatement costs and damage functions. In decentralized policies the interaction of many decision makers with their own assessments of the situation is the case. The interactions reveal the information feedback in contrast to where the knowledge was providing the feedback in centralized policies.

\subsection{COST EFFECTIVENESS}

Here it is hypothesized that polluter has more information than public policymakers on pollution control costs. In our case it might be vice versa. Anyways, policies do create incentives for the industry to achieve cost effective pollution control using their own private information regarding the costs of alternative pollution control technologies.

\subsection{Fairness}

"Equity is, first and foremost, a matter of morality and the concerns about how the benefits and costs of environmental improvements ought to be distributed among members of society. The notion of equity and fairness is somewhat not simple as the benefits and cost may lie distant in time and space therefore apparently seeming not equitable may be a most 
desired situation in long run providing both efficiency and equity. What is socially efficient from the perspective of a single state may not be from a national viewpoint because, for example, a state may not take account of externalities running to other states. When evaluating different environmental regulations and programs, one has to keep in mind the perspective from which this evaluation is done.

If blasting in Buner is stopped the miners won't be able to compete with other districts where blasting is allowed, hence to achieve the fairness the policy of stopping the blasting needs to be adopted nationally. The notion of 'environmental justice' come in play where mines are disproportionately situated in a province or country where the poor population is exposed to the harms related to the mining and processing of marble.

\subsection{Enforceability}

When it comes to enforcement as a criterion for the policy evaluation, EPA directly comes into play and it is seen that 'political will' is becoming the impediment in enforcement. Be it a blame or reality, but EPA has failed the nation in fulfilling its mandate.

\subsection{Flexibility}

Considering the information feedback from within the system to respond to certain conditions from the policy perspective will make a certain policy flexible. This means an essential use of arrays of situations where flexibility is required needs to be displayed. If the CAC provision such as NEQs are flexible and adjustable with time might look socially inefficient in short run but in the long run will prove to be efficient.

\subsection{Incentives for Technological Innovations}

CAC approach such as technology standards implementation is recommended for highly costeffective technologies where the 'abatement costs' are known to the regulator to be very low on the other hand IB strategies provide incentive for the adoption of commercially available technologies.

\subsection{Moral Considerations}

The way people think about environment and how they value fairness is given weightage in a comprehensive policy instruments where educating and giving awareness to the society on ethical grounds become inevitable to avoid policy resistance. We mostly discourage the subsidy policy however in this situation this might work differently, however we can find the discussion on this in path dependence discussion of our model, where a disturbance and positive feedback is there in a system for growth [29].

\section{CANDID POLICY APPROACHES}

\subsection{Command and-Control: Strategies (CAC): Standards}

An approach to policy where the socially efficient change is made obligatory on polluter in law by public representatives and then enforcement machinery takes all necessary steps to get it complied. CAC approach means reliance on standards. Marble industry to meet emission standards will treat its effluents, the costs to comply with standards are basically the 'total abatement costs' borne by the marble factory. The apparently simple CAC approach and appealing in normative sense to majority is in depth a lot more complex.

The three types of environmental standards mentioned by Field and Field [3] are ambient, emission, and technology standards. An ambient standard can be for air, water etc., such as setting different limits for different parameters like turbidity, Biochemical Oxygen Demand (BOD), Chemical Oxygen Demand (COD) and Total Suspended Solids (TSS) in water bodies. These can only be enforced through emissions that later lead to the ambient permissible levels expressed in terms of average concentration level over some duration of time. The assimilative capacity or the absorption capacity of nature is important factor which remains in the middle of both ambient and emission levels. The requirement by EPA on marble factories to construct settling tanks is technology standard, which also include design and engineering standards. There can also be standards applied on the products like codes given to marble finished or unfinished blocks and tiles. Thus, asking miners to use wire saws only will be a technology standard imposed on them while asking them to limit entry of pollutants into air from mining activities will make it an emission standard. In 
actual conditions, instruments may use combination of all three standards. To achieve economic efficiency in the CAC approaches the standards need to be set at efficient emission levels. Discussing dimension stone sector in which from extraction, transportation and processing and over its entire value chain standards may not be applied uniformly across the whole region. The tailored policy to each differing situation, for instance marble cities, districts with many factories, area with large mines etc. will be more efficient in terms of impacts but more costly in terms of getting the information needed to set the diverse standards and enforcing them.

Here it is desired to answer; What kind of standards ought to be applied on marble sector? The justification for each standard lies in the answer whether 'marginal abatement costs' vary across sources of emissions or not. The equal standard approach fails when there is marked difference between marginal abatement costs among sources [3].

The CAC approach based on standards is thought to be deficient in creating incentives for polluters to reduce the pollution. Asking marble factories to use settling tanks to reduce the wastes into streams limits them to find better approaches. Emission standards are better than technology standards in not draining off the incentive in pollution control to develop new ideas.

For enforcement of standards another cost comes into play, which is 'marginal penalty costs'. The CAC approaches are inherently flexible in their enforcements.

\subsection{IB Strategies: Emission Charges and Subsidies}

CAC approaches are thought to be deficient in deriving private information from the polluters and the information to the regulator thus comes at a substantial cost, which at times agency might not be in a position to bear. Incentive-based IB strategies are well suited in such instances [3]. Two types of incentive policies are:

1. Charges (taxes) and subsidies, and

2. Market-based systems.

To marble factory owners who do not seem to take into account the social costs as damage to environment occurring from their activities, one approach is to control the emissions by taxing them either per unit of emission or by subsidizing for each unit of reduction in emission at the source. Emission taxes are based on 'Polluters pay' principle, thereby paying for the ecological services. The incentive for the polluter here is to find the best possible way to reduce pollution. The tax system ends up in costing the factory more than through CAC approach. A rationale needs to be developed for dimension stone sector in Pakistan as to what kind of policies need to be adopted. The baseline scenario is already CAC based and that is the one polluting firm might prefer too, however society can benefit from the taxes rather than standards. The correct rate determination by the policy makers at the beginning is the key factor in implementing this IB strategy. IB approaches satisfies 'equimarginal principle' automatically even if the same tax applied across all the sources irrespective of their 'marginal abatement costs', each source would reduce pollution load and equalization will occur across all sources. If it is assumed that EPA in Pakistan and specifically in $\mathrm{KP}$ lacks information on marginal abatement costs of the marble factories then equimarginal principle can straightaway be applied with IB strategies. In cases where the emissions are distributed non uniformly, a single tax will address only marginal abatement cost, not differences in damages caused by the emissions from different sources the best suited instrument under these circumstances is 'zoned emission charge'. The Marble cities, industrial zones and zones for quarrying can be dealt under this instrument. The agencies come across different uncertainties such as marginal costs of abatement, emissions produced, in such circumstances emission charges bring about cost effectiveness. The enforcement of emission charges requires strict monitoring and its monitoring costs are more than required for CAC approaches [3]. Charges on emissions have the greatest leverage in terms of altering the incentives of polluters. This particular presumption can be tested on dynamic model to be developed under this project.

\section{CONCLUSIONS}

'Market failure' is the consequence of unregulated markets. This is true when environmental quality is seen as a 'public good'. For controlling such situations public policy is inevitable, which seems missing in our 
case. Another type of failure, that makes the outcome of public policy somewhat problematic is called 'government failure', which refers to systematic tendencies and incentives within legislatures and regulating agencies that work against the attainment of efficient and equitable public policy [3]. All this happens in 'complex situations' where vantage points matter. Only looking in the right direction sometimes solve the most wicked problems. There are different sectors at stake due to dimension stone industry and each sector is governed by its own policy and laws therefore in a coexisting policies and regulations it is concluded to develop integrated assessment models where multi-sectoral policies can be tested on system dynamics model.

The penalties will increase with the violation of emission standards, which incentivize the polluter to remain well under the limits. To get higher level of compliance more resources need to be diverted towards enforcement. Here the advancements in remote monitoring technology needs to be incorporated and the provisions of environmental audits and strategic environmental assessment policy instruments come into direct play, which are totally missing in current regimes. Fines have to be set in accordance with the abatement costs i.e., not to be too low as compared to the abatement costs. In case of technology standards, monitoring agency has to carry out both initial and running compliance audits. During selection of CAC approaches enforcement costs must therefore be borne in mind by the policy makers.

When local government starts charging for the ecological services rendered to the polluters unaccounted so far. Dimension stone sector will now add abatement costs and tax payments and will eventually charge the user thus making the emission charges 'transfer payments' in environmental economics terminology. The EPA in collaboration with local government and mine and mineral department may divide a territory into separate zones; Now the agency can charge on emissions differently on different zones.

If Factory Act, Industrial Relations Act get enforced, their effect would be employment taxes. The government then can reduce its employment taxes by generating a subsidy for the industry while increasing the emission taxes, so that that the total tax revenue of the government still remains the same.

From the political stand-point in Buner where it is tax free zone it would be easy for people to agree on a pollution control policy that begins by distributing valuable new rights than by notifying people to be taxed. This brings another IB strategy known as Cap and trade (CAP). One of the objectives of our study is to align the competitive pressures that exist in both domestic and international markets with the societal benefits by incorporating the policies, which are socially efficient.

\section{ACKNOWLEDGEMENT}

The authors are grateful to The Higher Education Commission of Pakistan for financial support of this research under the Technology Development Fund project TDF02-052 titled 'Marble Industry: A Case Study on Industrial Symbiosis, envisioning Zero Waste'.

\section{REFERENCES}

1. Rehan R., Nehdi M., "Carbon dioxide emissions and climate change: policy implications for the cement industry", Environmental Science and Policy, Vol. 8, No. 2005, pp. 105-114, 2012.

2. KP EPA, "Khyber Pakhtunkhwa Climate Change Policy: Environmental Protection Agency Govt. of KP Forestry", Environement and Wildlife Department, June 2016.

3. Field B. C., Field M. K., "Environmental Economics: An Introduction", Mc Graw Hill Education, 2017.

4. Liu Z., Mao X., Tu J., Jaccard M., “A comparative assessment of economic-incentive and commandand-control instruments for air pollution and CO2control in China's iron and steel sector", Journal of Environmental Management, Vol. 144, pp. 135-142, 2014.

5. Morecroft J. D. W., "System dynamics and microworlds for policymakers", European Journal of Operational Research, Vol. 35, pp. 301-320, 1988.

6. Bojan V., "Economic instruments in environmental policy", Environmental Policy and 
Law, Vol. 20, No. 4-5, pp. 140-143, 1990.

7. National Water Policy, 2018.

8. "The Khyber Pakhtunkhwa Minerals Sector Governance Act,2017', Khyber Pakhtunkhwa Act No. XXXVI of 2017. pp. 1-103, 2017.

9. Khyber Pakhtunkhwa, "Khyber Pakhtunkhwa Minerals Policy 2014", 2014.

10. Khyber Pakhtunkhwa Provincial Assembly Secretariat, "The Khyber Pakhtunkhwa Environmental Protection Act 2014", 2014.

11. Goverment of Khyber Pakhtunkhwa, "Industrial Policy Khyber Pakhtunkhwa 2016”, 2016.

12. Local Government, "The Khyber Pakhtunkhwa Local Government ACT, 2013", Act No.XXVIII of 2013, 2013.

13. "KP_Policy_Agriculture", 2013.

14. "Pakistan Environmental Protection Act, 1997", Act No. XXXIV of 1997.

15. Khyber Pakhtunkhwa Government, "The Khyber Pakhtunkhwa Factories ACT, 2013”, No. Xvi, 2013.

16. Khyber Pakhtunkhwa Government, "The Khyber Pakhtunkhwa Industrial Relations ACT, 2010", No. Xvi, 2010.

17. Kamal S., "Think Tank on the Rational Use of Water", Hisaar Foundation, 2016.

18. Urmar I., Ahmad J., "Khyber Pakhtunkhwa Climate Change Policy", Environmental Protection Agency Government of Khyber Pakhunkhwa Forestry, Environment \& Wildlife Department, 2016.

19. Natural Stone Council, "Best Practices of the Natural Stone Industry", Centre for Clean Products, The University of Tennessee, September 2018.

20. Cangioli S., "Life of water is man life-Minimize the water footprint of the impactful water waste in the cutting cycle of natural stone blocks", European Commission, 2013. Available at: https://webgate.ec.europa.eu/life/publicWebsite/i ndex.cfm?fuseaction=search.dspPage\&n_proj_id $=4557 \&$ doc $T y p e=$ pdf.

21. Pastakia F., "Environmental Protection and The Eighteenth Amendment", International Union for Conservation of Nature, April, 2012.

22. Afridi Z., "Khyber Pakhtunhwa Minerals Policy2014", 2014. Available at: http://www.pgjdc.org/Products/Contents/Mineral
-Policy-KPKdoc166.pdf

23. Chemonics International Inc, "USAID/ Pakistan Non- Agricultural Value Chain Assessment: as author", Asia and the Middle East Economic Growth Best Practices Project 2013. Available at: https://banyanglobal.com/wpcontent/uploads/2017/07/USAID-Pakistan-NonAgricultural-Value-Chain-Assessment.pdf

24. Curran T., Williams I. D., "A zero waste vision for industrial networks in Europe," Journal of Hazourdous Materials", Vol. 207-208, No. 2012, pp. 3-7, 2014.

25. V. \& Associates Mary Louise Vitelli, Esq., "International Best Practice Mining Policy: KPK \& Balochistan, Business Enabling Environment, Work Plan Level 33000, Action ID number 6704: as author", 2013.

26. Chemonics International, Vitelli \& Associates, "Assessing the Mineral Policy Frameworks Balochistan and Khyber Pakhtunkhwa", 2013.

27. Coglianese C., "Measuring Regulatory Performance Evalauating. The Impact of Regualtion and Regulatory Policy", Organization for Economic Co-Operation and Development August 2012. Available at: https://www.oecd.org/gov/regulatorypolicy/1_coglianese\%20web.pdf

28. Johansson B., "Climate policy instruments and industry - effects and potential responses in the Swedish context", Energy Policy, Vol. 34, No. 15, pp. 2344-2360, 2006.

29. Sterman J. D., Systems Thinking and Modeling for a Complex World, Massachusetts Institute of Technology ESD Internal Symposium, May 29302002 . 